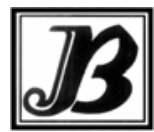

J. bio-sci. 20: 67-74, 2012

ISSN 1023-8654

http://www.banglajol.info/index.php/JBS/index

\title{
THE STUDY OF FILLET PROXIMATE COMPOSITION, GROWTH PERFORMANCE AND SURVIVAL RATE OF STRIPED CATFISH (PANGASIUS HYPOPHTHALMUS) FED WITH DIETS CONTAINING DIFFERENT AMOUNTS OF ALPHA-TOCOPHEROL (VITAMIN-E)
}

\author{
Syeda Mushahida-Al-Noor ${ }^{1 *}$, Md Delwer Hossain ${ }^{1}$, Md Amirul Islam ${ }^{2}$ \\ ${ }^{1}$ Department of Fisheries, Faculty of Agriculture, ${ }^{2}$ Department of Biochemistry and Molecular Biology, \\ Faculty of Science, University of Rajshahi, Rajshahi-6205, Bangladesh
}

\begin{abstract}
Context: Alpha-tocopherol has significant effect on the growth performance and fillet proximate composition of Striped Catfish (Pangasius hypophthalmus).

Objectives: To study the effect of DL-alpha tocopheryl acetate on the fillet proximate composition (moisture, crude protein, crude lipid, ash and alpha-tocopherol), survival rate and growth performance (SGR, weight gain, PWG) of $P$. hypophthalmus.

Materials and methods: Striped Catfish were fed with three trial diets (diet-1, diet-2 and diet-3) were prepared by adding different amounts of alpha-tocopheryl acetate (ATA, 0, 90 and $300 \mathrm{mgKg}^{-1}$ diet), over a period of 122 days. In each pond, $10 \%$ of the total fish were randomly selected and individually weighed once every fortnight and growth parameters were determined after each weighing. Moisture, dry matter, crude protein, lipid, ash and alpha-tocopherol of the experimental diets and fish fillet were determined by Conventional procedure, standard test method, micro-kjeldahl method, Bligh and Dyer method, standard methods and chromatographic method, respectively.

Results: Fish that were fed $90 \mathrm{mg} \mathrm{kg-1}$ and $300 \mathrm{mg} \mathrm{kg}^{-1}$ ATA supplemented diets had significantly higher growth performance than fish that were fed only farm processed diet $(P<0.05)$. The fillet protein, lipid content and alpha tocopherol level of the fish flesh were increased due to ATA supplementation in diets. The vitamin-E levels in fish fillet reflected dietary ATA levels. These results showed that fish on Diets 2 (supplemented with $90 \mathrm{mgKg}^{-1}$ ATA) and Diet 3 (supplemented with $300 \mathrm{mg} \mathrm{kg}^{-1}$ ATA) had significantly better production and resulted better flesh quality of fish than those on Diet 1 (without ATA supplementation).

Conclusion: Scanty information is available on the fillet proximate composition and growth performance of $P$. hypophthalmus fed with diets containing different amounts of alpha-tocopherol. The present study provides baseline information for establishing improved and profitable cultured system of the fish in impounds water of Bangladesh.
\end{abstract}

Key words: Nutrition, vitamin supplementation, alpha-tocopheryl-acetate, weight gain, Flesh's proximate composition.

Introduction

Pangasius hypophthalmus is widely produced around the world because of its proved attractive for its robust characteristics, rapid growth rates and high productivity compared to other species. It is desirable for striped catfish feed to be high in lipid content, with the aim of improving growth performance. However, high levels of dietary lipid leads to increased lipid content in the entire body of fish (Lie 2001, Chaiyapechara et al. 2003). The dietary lipids for fish culture are high in polyunsaturated fatty acid content and the polyunsaturated fatty

*Corresponding author E-mail: munianoor@gmail.com 
acids are readily incorporated into fillets of fish. In absence of natural antioxidants such as vitamin-E, fish quality may be affected due to degradation of the fish fillet through lipid oxidation. Therefore, diets should be fortified with appropriate amounts of antioxidants (Jensen et al. 1998, Chaiyapechara et al. 2003). Vitamin-E is a lipid-soluble vitamin and a natural antioxidant. Alpha-tocopherol acetate (ATA) is used as a vitamin-E source in fish feed in aquaculture, with the aim of improving fish growth (Hamre et al. 1998, Kaushik et al., 1998, Huo et al. 1999). The effects of including varying amounts of vitamin-E on the quality of fish fillet has been studied for several species such as Rainbow trout (Boggio et al. 1985, Frigg et al. 1990, Jensen et al., 1998, Chaiyapechara et al. 2003), Channel catfish (Bai and Gatlin 1993), Sea bass (Gatta et al. 2000), Atlantic salmon (Waagbo et al.1993, Hamre et al. 1998, Scaife et al. 2000), turbot (Ruffe et al. 2003), Catfish (Lim et al. 2001), Nile tilapia (Gammanpila et al. 2007), Sunshine bass (Trushenski 1999) and hybrid Tilapia (Huang et al. 2003).

This study was carried out to examine the effects of farm made feeds containing with low lipid and protein and different levels of ATA, on the growth performance, survival rate and proximate composition of the fillet in striped catfish.

\section{Materials and Methods}

\section{Fish and Experimental Diets}

The study was conducted at University of Rajshahi's Faculty of Agriculture, Department of Fisheries, Bangladesh (July to November, 2011). The experimental diets were prepared by adding $0 \mathrm{mg} \mathrm{kg}^{-1}$ (Diet 1), $90 \mathrm{mg} \mathrm{kg}^{-1}$ (Diet 2) and $300 \mathrm{mg} \mathrm{kg}^{-1}$ (Diet 3) of DL-alpha-tocopheryl acetate dry powder (ACl Company Ltd., Dhaka, Bangladesh) to a farm-made striped catfish diet produced with rice bran, boiled rice and mustard oil cake. The actual levels of vitamin- $E$ in the experimental diets were $90.2 \pm 0.2,192.5 \pm 0.4$ and $386.9 \pm 0.3$ mg kg-1 (because the feed ingredients also contains indigenous vitamin E), respectively, as shown in Table 1. Striped catfish fingerlings with a mean initial weight of $125.05 \pm 0.50 \mathrm{~g}( \pm \mathrm{SE}, \mathrm{n}=200)$ were randomly allocated to three treatments $\left(T_{1}, T_{2}, T_{3}\right.$ with two replication each) in six ponds and fed the experimental diets once daily for 122 days. The daily feeding rations were adjusted to $5 \%$ of body weight.

\section{Growth Performance}

In each pond, $10 \%$ of the total fish were randomly selected and individually weighted once every two weeks, and daily rations were determined after each weighting. The body weight gain (BWG) was calculated using the following equation: BWG $(\mathrm{g})=$ final weight $(\mathrm{g})$-initial weight $(\mathrm{g})$. The specific growth rate (SGR) was calculated using the following equation: SGR $\left(\% \mathrm{bwd}^{-1}\right)=[($ In final weight-In initial weight $) \times 100 /$ time in days]. The percentage weight gain (PWG) was calculated using the following equation: PWG (\%) $=[($ final weight- initial weight) $\times 100$ / initial weight]. The survival rate was calculated using the following equation: Survival rate $(\%)=[($ Number of harvested fish/Number of stocked fish $) \times 100]$.

\section{Proximate Analysis}

Twenty random samples, each month were killed and submitted for analysis of fillet composition. The fillets were blended prior to proximate analysis. Moisture, dry matter, crude protein, lipid, ash and alpha-tocopherol of the experimental diets and fish fillet were determined by Conventional procedure (ICOMR, 1971), Standard test method (ASTM 2003), Micro-kjeldahl method (Rangama 1979), Bligh and Dyer method (1959), Standard methods (AOAC 1998) and Chromatographic method (Huo et al.1999). 


\section{Statistical Analysis}

The difference between the growth performance and body composition among groups were analyzed with one-way analysis of variance (ANOVA) and Duncan's multiple range test (Duncan 1955) with a statistical package program (SSPS version 11.0) for $\mathrm{P}<0.05$ at the end of feeding trials.

\section{Results}

\section{Effect on diet compositions}

Chemical composition of the diets supplemented with different level of alpha-tocopherol shown in Table 1 where it is observed that addition of DL-alpha-tocopheryl acetate does not show significant difference in case of ash content $(P>0.05)$, but is significant in case of alpha-tocopherol amount $(P<0.05)$, of the diet extract in $\mathrm{T}_{2}$ and $\mathrm{T}_{3}$. Supplementation of DL-alpha-tocopheryl acetate in diets increased the dry matter, crude protein and lipid level slightly in case of diet-2 and diet-3.

Table 1. Chemical composition of the experimented diets during the study period.

\begin{tabular}{cccc}
\hline Chemical composition & Diet-1(used in $\left.\mathrm{T}_{1}\right)$ & Diet-2(used in $\left.\mathrm{T}_{2}\right)$ & Diet-3(used in $\left.\mathrm{T}_{3}\right)$ \\
\hline Dry matter $(\mathrm{g} / 100 \mathrm{~g})$ & $58.6 \pm 0.2$ & $60.3 \pm 0.3$ & $60.1 \pm 0.5$ \\
Crude protein $(\mathrm{g} / 100 \mathrm{~g})$ & $21.8 \pm 0.4$ & $22.8 \pm 0.3$ & $22.4 \pm 0.2$ \\
Crude lipid $(\mathrm{g} / 100 \mathrm{~g})$ & $13.7 \pm 0.1$ & $15.6 \pm 0.2$ & $15.8 \pm 0.6$ \\
Ash $(\mathrm{g} / 100 \mathrm{~g})$ & $1.8 \pm 0.6$ & $1.2 \pm 0.2$ & $1.3 \pm 0.3$ \\
Alpha-tocopherol $\left(\mathrm{mgKg}^{-1}\right)$ & $94.2 \pm 0.2$ & $192.5 \pm 0.4$ & $386.9 \pm 0.3$ \\
\hline
\end{tabular}

\section{Effect on growth performances}

The body weight gain (BWG), percentage weight gain (PWG) and specific growth rate (SGR) of striped catfish fed diets supplemented with $0 \mathrm{mg} \mathrm{kg}^{-1}, 90 \mathrm{mg} \mathrm{kg}^{-1}$ and $300 \mathrm{mg} \mathrm{kg}^{-1}$ ATA differed significantly from one another ( $P<0.05$, Table 2). Monthly variation on the body weight gain (BWG), percentage weight gain (PWG) and specific growth rate (SGR) was also observed during the study. The minimum weight gain $(49.00 \pm 0.78 \mathrm{~g})$ was recorded with treatment $T_{1}$ at 1 st month where the maximum weight gain $(504.00 \pm 0.52 \mathrm{~g})$ was recorded with treatment $\mathrm{T}_{2}$ at $3^{\text {rd }}$ month (Fig.1). The minimum percentage weight gain $(37.69 \pm 0.21 \%)$ was recorded with treatment $T_{1}$ at 1 st month where the maximum percentage weight gain $(89.32 \pm 0.56 \%)$ was recorded with treatment $T_{2}$ at $4^{\text {th }}$ month (Fig. 2). The minimum SGR $(1.03 \pm 0.021 \%)$ was recorded with treatment $T_{1}$ at 1st month where the maximum SGR $(2.05 \pm 0.047 \%)$ was recorded with treatment $\mathrm{T}_{2}$ at $4^{\text {th }}$ month (Fig. 3 ). The survival rate was affected by dietary ATA supplementation ( $P<0.05$, Fig. 4). In case of Survival rate (\%), the minimum value was recorded with treatment $T_{1}$ where the maximum value was recorded with treatment $\mathrm{T}_{2}$.

Table 2. Variation in the mean values of growth parameters under different treatments during the study period.

\begin{tabular}{cccc}
\hline Growth performance & $\mathrm{T}_{1}$ & $\mathrm{~T}_{2}$ & $\mathrm{~T}_{3}$ \\
\hline Weight gain(g) & $154.75 \pm 0.59$ & $250.00 \pm 0.68$ & $201.25 \pm 0.54$ \\
Percentage weight gain(\%) & $55.26 \pm 0.30$ & $73.91 \pm 0.47$ & $65.23 \pm 0.62$ \\
SGR $\left(\%\right.$ bwd $\left.^{-1}\right)$ & $1.44 \pm 0.054$ & $1.80 \pm 0.045$ & $1.63 \pm 0.060$ \\
Survival rate(\%) & $55.31 \pm 0.0016$ & $75.14 \pm 0.0013$ & $69.73 \pm 0.0023$ \\
\hline
\end{tabular}




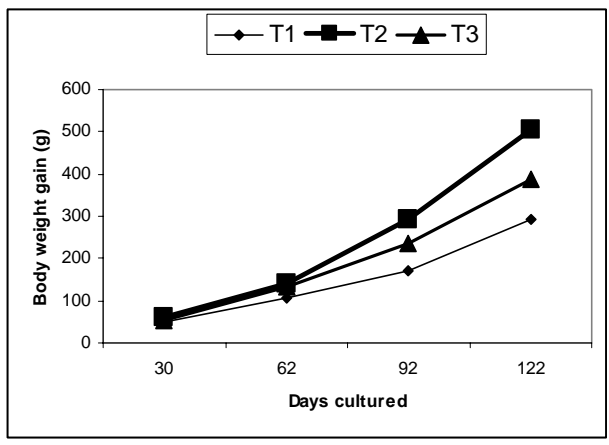

Fig 1. Monthly variation in body weight gain of fish with alphatocopheryl supplemented diets (diet-1, diet-2 and diet-3)

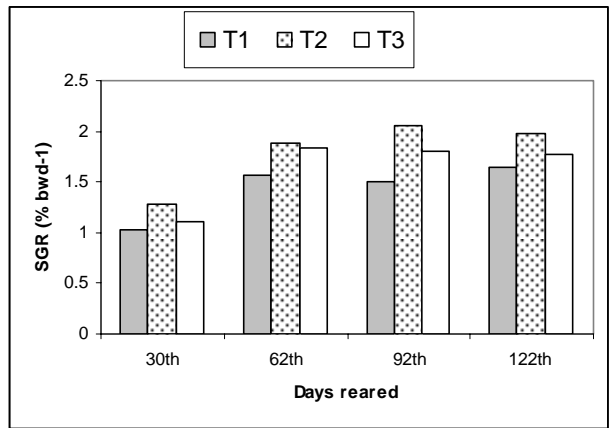

Fig 3. Monthly variation in specific growth rate of fish with alphatocopheryl supplemented diets (diet-1, diet-2 and diet-3)

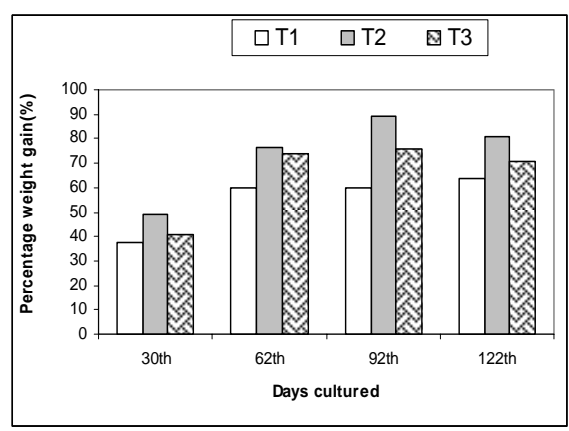

Fig 2. Monthly variation in percentage weight gain of fish with alpha-tocopheryl supplemented diets (diet-1,diet-2 and diet-3)

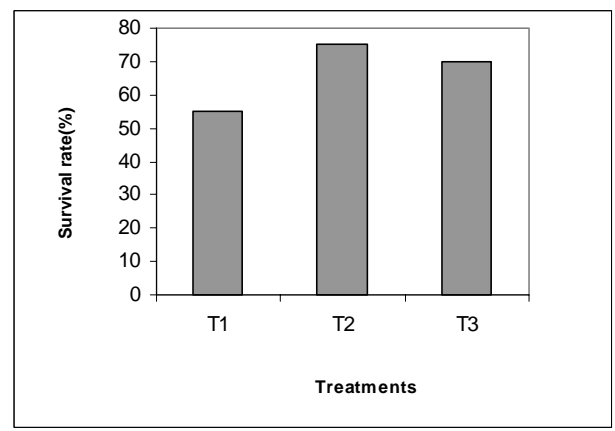

Fig 4. Survival rate of fish with DL-alpha-tocopheryl acetate supplemented diets (diet-1, diet-2 and diet-3)

\section{Effect on proximate composition of the fillet}

Table 3 shows the proximate composition of the fillets of Pangasius hypophthalamus under different treatment during the study period. The moisture, crude protein, crude lipid and ash content of fish fillets were affected variously by changes in dietary vitamin-E level from DL-alpha tocopheryl acetate supplementation (Table 3). The fillet moisture level and ash content decreased in comparison to initial values at $T_{1}(P<0.05)$. The fillet lipid level of experimental fish on Diet 1 was lower $(P<0.05)$ than for those on Diets 2 and 3 (Table 3). Fillet lipid increased from an initial value of $4.08 \pm 0.15 \%$ to $8.08 \pm 0.18 \%$ and $8.01 \pm 0.16 \%$, respectively $(P<0.05)$. The highest amount of lipid was found in the fish fillet on Diet $2(8.08 \pm 0.18 \%)$ and the lowest amount was found in the fish on Diet $1(4.08 \pm 0.15 \%)$. The fillet moisture level of experimental fish on Diet 1 was higher $(P>0.05)$ than for those on Diets 2 and 3 (Table 3). Fillet moisture decreased from an initial value of $79.15 \pm 0.10$ to $74.20 \pm 0.10$ and $74.10 \pm 0.20$, respectively ( $P>0.05$ ). The highest amount of moisture was found in the fish on Diet $1(79.15 \pm 0.10 \%)$ and the lowest amount was found in the fish on Diet $3(74.10 \pm$ $0.2 \%)$. The fillet ash content of experimental fish on Diet 1 was higher than for those in both Diet 2 and 3 (Table 3). 
Table 3. Proximate composition of the fillets of Pangasius hypophthalamus under different treatment during the study period.

\begin{tabular}{|c|c|c|c|}
\hline Proximate composition & $\mathrm{T}_{1}($ Fed D-1) & $\mathrm{T}_{2}($ Fed D-2) & $\mathrm{T}_{3}($ Fed D-3) \\
\hline Moisture $(\mathrm{g} / 100 \mathrm{~g})$ & $79.15 \pm 0.10$ & $74.20 \pm 0.10$ & $74.10 \pm 0.20$ \\
\hline Crude protein $(\mathrm{g} / 100 \mathrm{~g})$ & $15.50 \pm 0.18$ & $16.40 \pm 0.23$ & $16.60 \pm 0.18$ \\
\hline Crude lipid $(\mathrm{g} / 100 \mathrm{~g})$ & $4.08 \pm 0.15$ & $8.08 \pm 0.18$ & $8.01 \pm 0.16$ \\
\hline Ash $(\mathrm{g} / 100 \mathrm{~g})$ & $1.24 \pm 0.10$ & $1.21 \pm 0.12$ & $1.20 \pm 0.13$ \\
\hline Alpha-tocopherol $\left(\mathrm{mgKg}^{-1}\right)$ & $9.55 \pm 0.18$ & $33.41 \pm 0.13$ & $34.58 \pm 0.20$ \\
\hline
\end{tabular}

Fillet ash content decreased from an initial value of $1.12 \pm 0.10$ to $1.21 \pm 0.12$ and $1.20 \pm 0.13$, respectively but the result is not significant. The highest amount of ash content was found in the fish on Diet $1(1.24 \pm 0.13 \%)$ and the lowest amount was found in the fish on Diet (1.20 $0.10 \%)$. Vitamin-E level (Alpha-tochopherol) increased significantly with increasing dietary ATA levels. The fillet vitamin-E content of fillet on Diets 1, 2, and 3 were $9.55 \pm 0.18,33.41 \pm 0.13$ and $34.58 \pm 0.20 \mathrm{mg} \mathrm{kg}-1$ diet, respectively $(P<0.05)$.

\section{Discussion}

The present study showed that the growth performances of $P$. hypophthalmus was significantly enhanced when different amounts $\left(0 \mathrm{mgKg}^{-1}, 90 \mathrm{mgKg}^{-1}\right.$ and $300 \mathrm{mgKg}^{-1}$ feed) of DL-alpha tocopheryl acetate (ATA) were added in farm processed feed. The result were in agreement with the previous findings for Chinook salmon (Woodall et al. 1964), channel catfish (Murai and Andrew 1974, Lovell et al. 1984, Wilson et al. 1984, Yildirim-Aksoy et al. 2008), rainbow trout (Cowey et al. 1983) and parrot fish (Galaz et al. 2010). In the present study, no significant change in growth performance was observed in higher a-TA levels $(300 \mathrm{mg} / \mathrm{kg}$ feed). The negative effects by a high dose of dietary a-TA have been reported with respect to growth performance in other fish species such as, parrot fish (Galaz et al., 2010), brook trout fry (Poston and Livingston, 1969), African catfish (Baker and Davies, 1996), and rainbow trout (Kiron et al. 2004), red drum (Sciaenops ocellatus, Li et al. 2008). In the present study the survival rate in case of $\mathrm{T}_{2}$ (Diet-2) and $\mathrm{T}_{3}$ (Diet3 ) is higher than $T_{1}$ (Diet-1). This result is supportive to Yildirim-Aksoy et al. (2008) in case of I. punctatus; Mehrad et al. (2012) in case of Danio, Onivie et al. (2010) in case of Heterobranchus longifilis and Mehrad and Saudagar (2010) in case of Guppy (Poecillia reticulate), Faramarzi (2012) in case of Angel Fish (Pterophyllum scalare) fed with Vitamin-E containing diet.

The present study showed that vitamin-E containing diet has significant effect on moisture, crude lipid, ash content and alpha-tocopherol level of the fillet. According to Jasour et al. (2011), the concentration of atocopherol in fillets increased linearly in response to feed alpha-tocopherol concentration $(P<0.05)$ in case of Oncorhynchus mykiss. The alpha-tocopherol content in turbot liver and muscle tissue was significantly influenced by dietary intake of a-tocopherol (Stephan et at. 1995). Gatta et. al. 2000) found a correlation between dietary Vitamin-E level and flesh deposition in sea bass (Dicentrarchus fabrax). Bai \& Lee (1998) found a linear relation between dietary levels of alpha-tocopheryl acetate with fillet vitamin $E$ content in Korean rockfish. Weatherup and McCracken (1999) state that lipid level in fish increases with growth which is similar to the present study. Yildiz (2004) proved that the fillet Vitamin-E content of the fish reflected their dietary ATA levels. This positive correlation between dietary and fillet Vitamin-E content is also reported for rainbow trout and other aquaculture species such as Atlantic salmon, sea bass, turbot and Atlantic halibut show comparable results (Bjerkeng et al. 1999, Pirini et. al. 2000, Ruff et. al. 2003, Stephan et al.1995). 


\section{Conclusion}

In conclusion, the conducted study demonstrated that diets containing different amount of alpha-tocopheryl acetate affect growth performance and led to increased vitamin $E$ and lipid content in the fish flesh. These results suggest that feeding the fish diets containing $90 \mathrm{mgKg}^{-1}$ and $300 \mathrm{mgkg}^{-1}$ alpha-tocopheryl acetate results in higher flesh quality and comparatively batter growth in case of $P$. hypophthalmus compared to diet1(diet without alpha-tocopheryl acetate).

\section{Acknowledgements}

This work is a part of the M.S. thesis of the first author, she is thankful to the Ministry of Science and Technology, Bangladesh for offering her National Science and Technology (NST) fellowship for accomplishing this research. We are grateful to Department of Fisheries, University of Rajshahi, Bangladesh for providing technical support. We also like to acknowledge the contribution of Laboratory of Protein and Enzyme Research, Department of Biochemistry and Molecular Biology, University of Rajshahi, Bangladesh for technical assistance during the study.

\section{References}

AOAC (Association of Official Analytical Chemistry). 1998. Official Methods of Analysis (16th Edition). Gaithersburg, Maryland, 20877-2417 USA. Vols. I and II, 4th Revision.

ASTM Standard C33. 2003. Specification for concrete aggregates, ASTM International, West Conshohocken, PA, http://dx.doi.org/10.1520/C0033-03

Bai SC, Gatlin DM.1993. Dietary Vitamin-E concentration and duration of feeding affect tissue alpha-tocopherol concentrations of channel catfish (Ictalurus punctatus). Aquaculture 113, 129-135. http://dx.doi.org/10.1016/00448486\%2893\%2990346-Z

Bai SC, Lee KJ. 1998. Different levels of dietary DL-alpha-tocopheryl acetate affect the Vitamin-E status of juvenile Korean rockfish, Sebastes schlegeli. Aquaculture 161, 405-414. http://dx.doi.org/10.1016/S0044-8486\%2897\%2900288$\underline{3}$

Baker RTM, Davies SJ. 1996. Oxidative nutritional stress associated with feeding rancid oils to African cat fish, Clarias gariepinus and the protective role of $\alpha$-tocopherol. Aquac Res 27, 795-803. http://dx.doi.org/10.1111/j.13652109.1996.tb01238.x

Bjerkeng B, Hamre K, Hatlen B, Wathne E. 1999. Astaxanthin deposition in fillets of Atlantic salmon Salmo salar L. fed two dietary levels of astaxanthin in combination with three levels of a-tocopheryl acetate. Aquacult Res 30(9), 637646. http://dx.doi.org/10.1046/i.1365-2109.1999.00355.x

Bligh EG, Dyer WJ. 1959. A rapid method of total lipid extraction and purification. Can J Biochem Physiol 37, 911-7. http://dx.doi.org/10.1139/059-099

Boggio RW, Hardy J, Babbitt K, Brannon EL. 1985. The influence of dietary lipid source and alpha-tocopheryl acetate level on product quality of rainbow trout (Salmo gairdneri). Aquaculture 51,13-24.

Chaiyapechara S, Casten MT, Hardy RW, Dong FM. 2003. Fish performance, fillet characteristics and health assessment index of rainbow trout (Oncorhynchus mykiss) fed diets containing adequate and high concentrations of lipid and vitamin-E. Aquaculture 219, 715-738. http://dx.doi.org/10.1016/S0044-8486\%2803\%2900025-5

Cowey CB, Adron JW, Youngson A. 1983. The Vitamin-E requirement of rainbow trout (Salmo gairdneri) given diets containing polyunsaturated fatty acid derived from fish oil. Aquaculture 30, 85-93. http://dx.doi.org/10.1016/00448486\%2883\%2990154-0

Duncan DB. 1955. Multiple ranges and multiple F test. Biometric 11, 1-42. http://dx.doi.org/10.2307/3001478 
Faramarzi M. 2012.Assessment Study about Effect of Vitamin-E ( $\alpha$-Tocopheryl) on Feeding Performance, Survival Rate and Reproductive Performance of Angel Fish (Pterophyllum scalare). World Journal of Fish and Marine Sciences 4 (3), 254-257.

Frigg M, Prabucki AL, Ruhdel EU. 1990. Effect of dietary Vitamin-E levels on oxidative stability of trout fillets. Aquaculture 187, 105-125.

Galaz GB, Sung-Sam K, Kyeong-Jun L. 2010. Effects of Different Dietary Vitamin-E Levels on Growth Performance, Non-specific Immune Responses, and Disease Resistance against Vibrio anguillarum in Parrot Fish (Oplegnathus fasciatus). Asian-Aust J Anim Sci 23, 916 - 923. http://dx.doi.org/10.5713/ajas.2010.90494

Gammanpila M, Yakupitiy A, Bart AN. 2007. Evaluation of the effect of dietary vitamin C, E and Zinc supplementation on the reproductive performance of Nile Tilapia (O. niloticus). Srilanka j Aquat Sci 12, 39-60.

Gatta PP, Pirini M, Testi S, Vignola G, Monetti PG. 2000. The influence of different levels of dietary Vitamin-E on sea bass Dicentrarchus labrax flesh quality. Aquacult Nutr 6, 47-52. http://dx.doi.org/10.1046/j.1365-2095.2000.00127.x

Hamre K, Berge RK, Lie O. 1998. Oxidative stability of Atlantic salmon (Salmo salar, L.) fillet enriched in alpha-, alphaand alpha-tocopherol through dietary supplementation. Food Chemistry 62 (2), 173-178. http://dx.doi.org/10.1016/S0308-8146\%2897\%2900209-4

Huang $\mathrm{CH}$, Chang RJ, Huang SL, Chen W. 2003. Dietary Vitamin-E supplementation affects tissue lipid peroxidation of hybrid tilapia, Oreochromis niloticus X O. aureus. Comp. Biochem Physiol B: Mol Biol 134,265-270.

Huo JZ, Nelis HJ, Lavens P, Sorgeloos P, De Leenheer AP. 1999. Simultaneous determination of alpha-tocopheryl acetate and tocopherols in aquatic organisms and fish feed. Journal of Chromatography 724, 249-255. http://dx.doi.org/10.1016/S1096-4959\%2802\%2900256-7

ICOMR. 1971. In: A Manual of Laboratory Techniques. Indian Council for Medical Research. National Institute of Nutrition, India . 2-6 pp.

Jasour MS, Rahimabadi EZ, Ehsan A, Rahnama M, Arshadi A. 2011. Effects of refrigerated storage on fillet lipid quality of rainbow trout(Oncorhynchus mykiss) supplementary by alpha-tocopheryl acetate through diet and direct addition after slaughtering. J Food Process Techno 2,124.

Jensen C, Birk E, Jokumsen A, Skibsted LH, Bertelsen G. 1998. Effect of dietary levels of fat, Alpha-tocopherol and astaxanthin on color and lipid oxidation during storage of frozen rainbow trout (Oncorhynchus mykiss) and during chill storage of smoked trout. Z Lebensm Forsch 207,189-96. http://dx.doi.org/10.1016/S1096-4959\%2802\%2900256-7

Kaushik SJ, Gouillou-Coustans MF, Cho CY. 1998. Application of the recommendations on vitamin requirements of finfish by NRC (1993) to salmonids and sea bass using practical and purified diets. Aquaculture 161, 463-474. http://dx.doi.org/10.1016/S0044-8486\%2897\%2900293-7

Kiron V, Puangkaew J, Ishizaka K, Satoh S, Watanabe T. 2004. Antioxidant status and nonspecific immune responses in rainbow trout (Oncorhynchus mykiss) fed two levels of Vitamin-E along with, three lipid sources. Aquaculture 234, 361-379. http://dx.doi.org/10.1016/j.aquaculture.2003.11.026

Li P, Wang X, Gatlin MIII. 2008. RRR-[alpha]-Tocophryl succinate is ales bio-available source of Vitamin-E than allrac[alpha]-tocophryl acetate for red drum Fciaenops ocellatus. Aquaculture 280,165-169. http://dx.doi.org/10.1016/i.aquaculture.2008.04.027

Lie 0. 2001. Flesh quality - the role of nutrition. Aquaculture Research 32 (1), 341-348. http://dx.doi.org/10.1046/j.1355557x.2001.00026.x

Lim PK, Boey PL, Ng WK. 2001. Dietary palm oil level affects growth performance, protein retention and tissue vitamin $\mathrm{E}$ concentration of African catfish, Clarias gariepinus. Aquaculture 202, 101-112. http://dx.doi.org/10.1016/S00448486\%2801\%2900563-4

Lovell RT, Miyazaki T, Rabegnator S. 1984. Requirements for a-tocopherol by channel catfish fed diets low in polyunsaturated triglycerides. J Nutr 114,894-901. 
Mehrad B, Jafrayan H, Taati MM. 2012. Assessment of the effects of dietary Vitamin-E on growth performance and reproduction of Zebra fish, Danio rerio(Pisces, Cyprinidae). J Ocean Mari Sci 3(1),1-7.

Mehrad B, Sudagar M. 2010. Dietary Vitamin-E requirement, fish performance and reproduction of guppy (Poecilia reticulata). AACL Bioflux, 3(3),229-231.

Murai T, Andrews JW. 1974. Interactions of dietary a-tocopherol, oxidized menhaden oil and ethoxyquin on channel catfish (Ictalurus punctatus). J Nutr 104, 1416-1431.

Onivie ILM., Olutimilehin AJ, Sunday OJ, Titus MC. 2010. Influence of Supplemental Vitamins C and E in Maternal Diets on Growth and Survival of Heterobranchus longifilis Fry Outdoor. Nature and Science 8(1), 26-38.

Pirini M, Gatta PP, Testi S, Trigari G, Monetti PG. 2000. Effect of refrigerated storage on muscle lipid quality of sea bass (Dicentrarchus labrax) fed on diets containing different levels of Vitamin-E. Food Chem 68, 289-296. http://dx.doi.org/10.1016/S0308-8146\%2899\%2900190-9

Poston HA, Livingston DL. 1969. Effects of massive doses of dietary Vitamin-E on fingering brook trout. Fish Res Bull $33,6-12$.

Rangama S. 1979. Manual of analysis of Fruits and Vegetable Products, Tata Mc Graw-Hill Publishing Company Ltd. New Delhi.

Ruff N, Fitzgerald RD, Cross TF, Hamre K, Kerry JP. 2003. The effect of dietary Vitamin-E and C level on market-size turbot (Scophthalmus maximus) fillet quality. Aquaculture Nutrition 9(2), 91-97. http://dx.doi.org/10.1046/j.13652095.2003.00230.x

Scaife JR, Onibi GE, Murray I, Fletcher TC, Houlihan DF. 2000. Influence of a-tocopherol acetate on the short-and longterm storage properties of fillets from Atlantic salmon Salmo salar fed a high lipid diet. Aquaculture Nutrition 6, 6571. http://dx.doi.org/10.1046/j.1365-2095.2000.00128.x

Stephan G, Guillaume J and Lamour F. 1995. Lipid peroxidation in turbot (Scophthalmus maximus) tissue: effect of dietary Vitamin-E and dietary n-6 or n-3 polyunsaturated fatty acid. Aquaculture 130, 251-268. http://dx.doi.org/10.1016/0044-8486\%2894\%2900322-F

Trushenski JT. 1999. Evaluation of natural source of Vitamin-E, RRR-a-tocopheryl acetate, as an alternative micronutrient source and nutricutical for Sunshine Bass( Morone chrysops X M. saxatilis) culture, Dissertation. USA: Graduate School of Southern Illinois, University of Carbondale.

Waagbo R, Sandnes K, Torrissen OJ, Sandvin A, Lie O.1993. Chemical and sensory evaluation of fillets from Atlantic salmon (Salmo salar) fed three different levels of n-3 polyunsaturated fatty acids at two levels of Vitamin-E. Food Chem 46, 361-366. http://dx.doi.org/10.1016/0308-8146\%2893\%2990005-Z

Weatherup RN, McCracken KJ. 1999. Changes in rainbow trout, Oncorhynchus mykiss (Walbaum), body composition with weight. Aquaculture Research 30, 305-307. http://dx.doi.org/10.1046/.1365-2109.1999.00320.x

Wilson RP, Bowser PR, Poe WE. 1984. Dietary Vitamin-E requirement of fingerling channel catfish. J Nutr 114, 20532058.

Woodall ANLM., Ashley JE, Halver HS, Van J. 1964. Nutrition of salmonoid fishes : XIII. The alpha-tocopherol requirement of Chinook salmon. J Nutr 84,125-135.

Yildirim-Aksoy M, Lim C, Li MH, Klesius PH. 2008. Interaction between dietary levels of vitamin C and E on growth and immune responses in channel catfish, Ictalurus punctatus. Aquaculture Research 39, 1198-1209. http://dx.doi.org/10.1111/j.1365-2109.2008.01984.x

Yildiz M. 2004. The study of fillet quality and the growth performance of Rainbow trout (Oncorhynchus mykiss) fed with diets containing different amounts of vitamin-E. Turkish Journal of Fisheries and Aquatic Science 4, 81-86. 